\title{
A Context-Aware Mobile-Based System for Crime Prevention and Emergencies
}

\author{
Sarifah Putri Raflesia ${ }^{1}$, Taufiqurrahman ${ }^{2}$, Dinda Lestarini ${ }^{3 *}$, Ali Bardadi ${ }^{4}$ \\ ${ }^{1,4}$ Department of Computer Science, Universitas Sriwijaya, Indralaya, Indonesia \\ ${ }^{2}$ Pusat Pertahanan Siber, Badan Instalasi Strategis Pertahanan Kementerian Pertahanan, Indonesia \\ ${ }^{3}$ Database and Big Data Laboratory, Universitas Sriwijaya, Indralaya, 30862, Indonesia
}

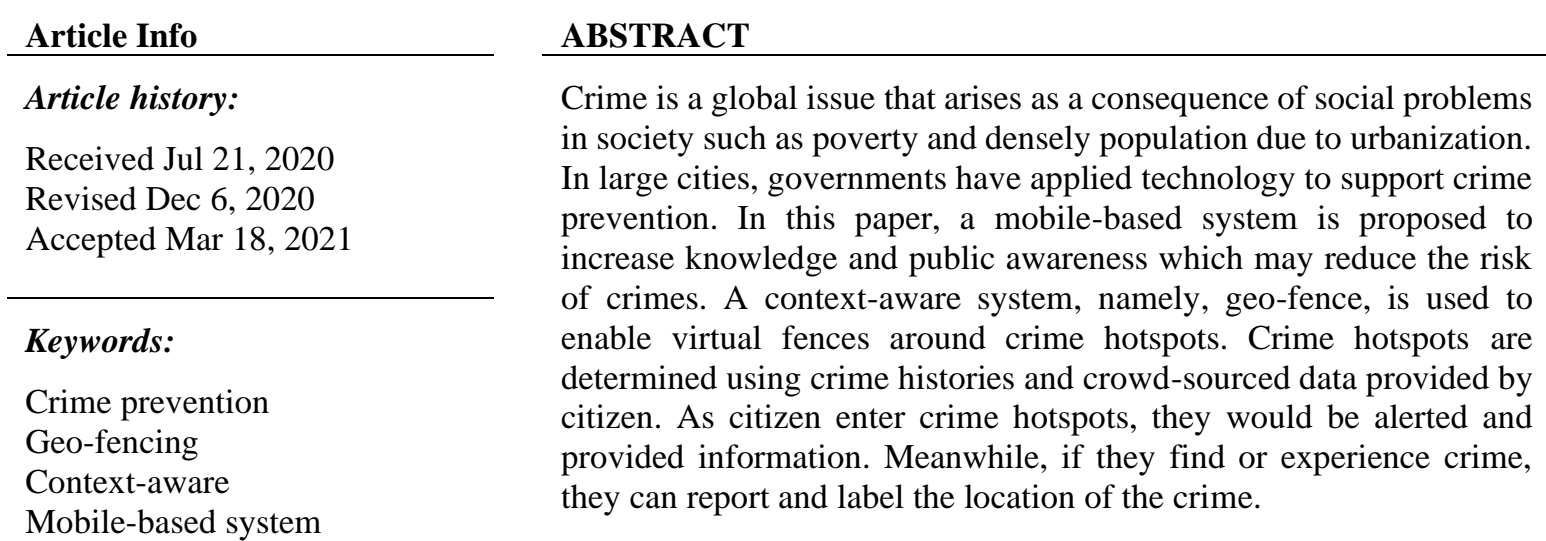

Copyright $\odot 2021$ Institute of Advanced Engineering and Science. All rights reserved.

\section{Corresponding Author: Dinda Lestarini}

Dinda Lestarini,

Database and Big Data Laboratory,

Universitas Sriwijaya, Indralaya, 30862, Indonesia

Email: dinda@unsri.ac.id

\section{INTRODUCTION}

Nowadays, poverty is a global issue that is a problem for developed and developing countries. Economic pressure has an impact on the level of security because it can lead to crime, most often street crime such as robbery, plunder, drug transactions, prostitution, acts of physical violence, and murder [1][2]. To overcome this problem, the government especially in big cities install closed-circuit television, provide 24hour call centers, and patrol police officers.

The issue of poverty and crime in urban areas does not stop the flow of urbanization. Urbanization continues to increase because large cities provide opportunities and can trigger rapid economic growth[3]. As a result, problems and challenges that must be overcome can arise such as increased crime and the urgency of a fast and responsive crime eradication. Crime and brutal actions have been the biggest fear [4] and this situation has gained important awareness includes the government [5]. At the same time with the increasing number of people, the government is also urged to make savings on resources. Therefore, many big cities are transformed into smart cities that utilize technology to integrate information and communication technology such as mobile devices to support and improve the effectiveness and efficiency of government services.

The smartphone is a technology that can be used as a support for smart cities. It enables the use of internet networks and provides interfaces for smart city applications such as maps, multimedia features, and social media. According to GSMA real-time intelligence data [6] over 5.13 Billion people worldwide using mobile devices. By means, $66.53 \%$ of the world's population have at least one mobile device. This creates new opportunities for the government to communicate with the public. Mobile phone has Global Positioning System (GPS) chip which can combine with software such as mobile operating system and other application to enable Location-Based Service (LBS). Some studies have developed a crime prevention system using LBS [7] [8] [9]. 
The systems are built to report and provide valuable information to users regarding crime prevention in spesific areas.

In this paper, a mobile-based system to support police operations in preventing crime in large cities is proposed. The system uses geo-fence to enable the administrator to create boundaries in crime hotspots area. A geo-fence works as virtual fence or a perimeter around a physical location [10][11]. When geo-fence is applied to certain locations and object enters this area, something that was previously set from administrator page is executed. In proposed system, every citizen who enters the geo-fenced area will be notified about potential crimes, nearest police station, and hospitals, on-duty police officers, gas station, and other safety information. When citizen are notified, they can choose to ignore or respond to the alerts. If the citizen gives response to notification, the system will provide further information and supports.

The determination of crime hotspot are not only engaging the criminal history and report but also the system employs crowdsource data. It aims to advance and enrich the real-time information base to support decisions focused around law reinforcement. Crowdsourcing is believed as an effective approach to facilitate collaboration between citizen and government [12]. Citizen can report a criminal act and provide multimedia files such as pictures or videos of their surroundings. Alternatively, citizen could respond with an audio recording of what they can hear in their present location. Once the citizen submits the data, police officers are immediately updated. This data will be validated by police officers to ensure the data is valid and can be used to determined crime hotspot areas.

Finally, notifying and monitoring the citizen does not mean that the system advises people to avoid certain areas but only suggests increased caution if they must be located in crime hotspots. Increasing knowledge about how to reduce the risk of victimization may help citizen to reduce negative perceptions such as fear and anxiety which tends to be higher than the actual crime risk itself.

\section{MATERIAL AND METHODS}

\subsection{Crime Prevention}

Social problems in society, such as poverty [13] and high population density [14], become critical factors that affect the increase of criminal rate, especially in large cities. Criminal issues are directly linked to public safety and social stability, and how to tackle the crime is foundation of effective state [15]. Therefore urban safety is a core element of urban sustainability to create a secure society. Crime prevention is no longer considered exclusive in a crime policy but also covers the area of public policy such as urban and social planning [16].

The number of violence and crime is related to certain degree of social breakdown [17]. Hence, increasing criminal rates requires government intervention to resolve the problem. Since strategic level decision making is related to crime rates [18]. The effectiveness and efficiency of crime prevention need to be discussed. How traditional crime prevention such as patrol can be supported by technological advantages. In this paper, the proposed system involves the police department as monitor 24 hours and public awareness. It is promoting smart city by engaging the used of technology to manage a city.

Nowadays, the government in developed and developing country promote the smart city concepts. By transforming the city into a smart city, the government can improve its services such as [19]:

- smart transport;

- smart energy;

- smart technology;

- smart living;

- smart environment;

- smart citizen and education;

- smart economy;

- smart government;

- safe city.

The smart city is directly related to the use of information and communication technology which can assist the government in increasing public, government, and non-government awareness. As mentioned previously, concept of smart city also includes safe city to prevent crime in certain areas and providing guidance to prevent crime [20]. Table 1 shows the technology innovation for crime prevention. 
Table 1. Technology innovations for crime prevention [21]

\begin{tabular}{|c|c|c|}
\hline & Hard Technology & Soft Technology \\
\hline
\end{tabular}

A mobile application has been developed for situational crime [7]. The application aimed to provide a convenient way in crime reporting and community policing. The application included reporting module, crime mapping, SMS, Tips, and Direct calls from the application. In this research, crime mapping feature didn't work as expected due to internet connectivity. Another research developed an android crime reporting system [8]. Google Map APIs and Google Places APIs have been employed to help the system to spot users' location and nearby police stations. The system offers alternative means to report the crime to police station, such as AppTo-App call, sending crime scene images, and recording the event using device microphone. This system has proved more effective to help user in reporting the crime timely than the conventional reporting system.

An android application to assist a user in dealing with criminal activity is developed [9]. The application use GPS to track users' location and recommend information about the nearest emergency point. When the crime happened, the users can notify stakeholders in that area to rescue the users as fast as possible. The stakeholders are including ambulance, nearest hospital, nearest friends and volunteers. The application is believed to help in reducing the time gap due to communicational issues.

Crime tends to concentrate in a certain area. The area with a higher number of crimes is called crime hotspot areas[22]. The crime hotspot areas can be determined by using the crime historical data. Usually, crime historical data can be acquired by users' reports to the police. The trend of social media usage creates an opportunity to acquire more information about potential crime, especially unreported crime. CROWDSAFE is an application that implements crowdsourcing concept to gather crime data[12]. Crowdsourcing is an effective approach to facilitate collaboration between citizen and government.

\subsection{Geo-fencing}

Geo-fences are virtual perimeters that mark locations in the physical world [23]. Geo-fences are often used in Location Based System (LBS) to provide information and service according to users' physical location as simulates in Figure 1. A current LBS application asks users to specify the location and selects a radius to activate the reminder delivery. A reminder is triggered when the user enters or exits the virtual fence [24]. In previous research, geo-fences have been commonly used to solve problem such as disaster mitigation. In disaster mitigation cases, Suyama et al [25] proposed disaster mitigation system using geo-fencing to monitor the users' movement and also provide risk information. In other cases [26], geo-fence is embedded to webbased application to notify users about accident-prone areas. Also, to contribute the child safety cases, geofence and movement sensor were embedded to wearable devices. The device can be used to monitor and automatically using movement sensors. to send the risk in form of multimedia information such as video and sound [27]. Furthermore, in other cases, geofence is included in the need for air vehicle autonomy [28]. This is directly related to safety and efficiency issues. Regarding the safety and efficiency of aircraft operations, one needs to establish a planned and dynamic flight path. Therefore, the concept of geofence provides a way to ensure safe and efficient path. 


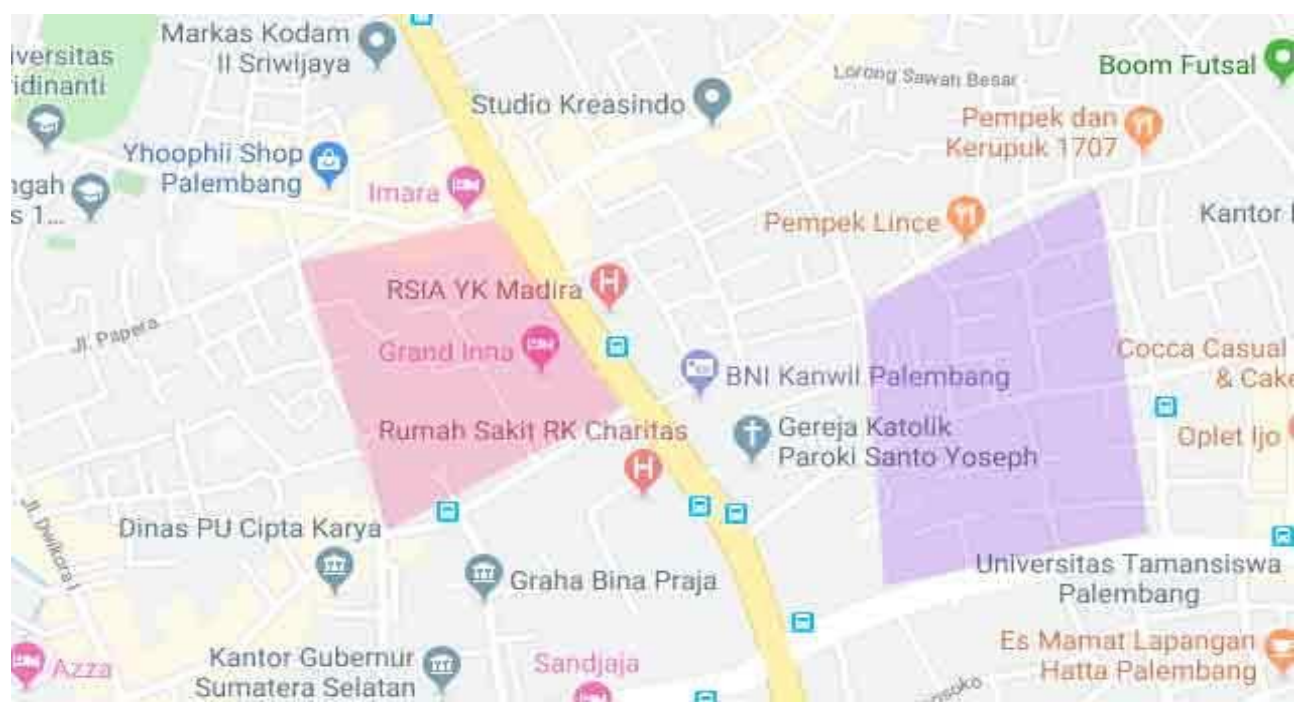

Figure 1. Geofencing areas on virtual map

Early implementation of geo-fencing involved cell tower identifiers to identify user whereabouts. By using data from mobile phone operators, they can send SMS marketing campaigns, track inventory and help in solving criminal cases. Nowadays, geo-fencing is implemented in mobile applications using modern technologies and techniques to monitor user whereabouts in a fenced area.

Three principles must be considered when implementing geo-fencing at the mobile application, namely the three Ps of mobile: permission, privacy, and preference [23]. If citizen download the application then it indicates that they are willing to engage in criminal preventing process. To make the geo-fence work, citizen need to give the system permission to use GPS. When citizen use the application, we need to respect their privacy by not tracking their movement when they are not in geo-fence area. In addition to that, we should use the application on the citizen' terms. We cannot provide them with irrelevant information or misuse their data. When they feel that the application does not meet their preference, they can decide to stop their engagement with the application.

\section{RESULTS AND DISCUSSION}

\subsection{System Development}

In this paper, a mobile-based system is proposed to support police operations in preventing crime in a large city. As shown in figure 2, the system can be accessed by two user groups, police and citizen. Police use the system to manage and monitor the crime hotspot in their territory. Meanwhile, the citizen use the system to support information acquisition and dissemination. The system will acquire information about crime hotspots through citizen reports. Moreover, the system facilitates disseminating information about crime prevention, such as emergency numbers and nearest safe places, to citizen. Web service accommodates the services to police and citizen through internet.

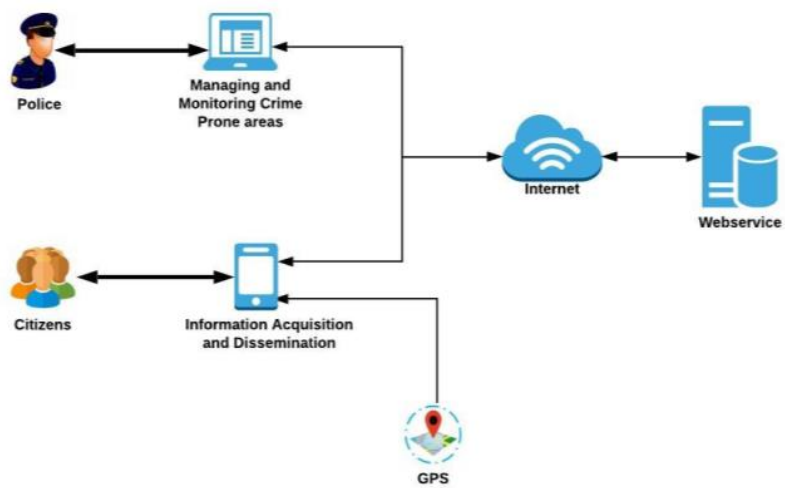

Figure 2. System Architecture 
The model is applied through application development that incorporates geo-fencing technique. Figure 3 describes the process flow of the system. Citizen, who use the application for the first time, have to register their data to the system. The system requires users to upload their national identity cards to ensure that there is no misuse of the application by irresponsible users. During registration, the system will also provide information about what data is required from the users and how the data is used. By giving consent to the system, the user legally allows the system to access the required data, including their physical position. The registered citizen can log into the system to avoid unauthorized users and the system will monitoring users' whereabout in the geo-fenced area. By knowing citizen' physical position, the system can show the crime hotspot area near them as shown in Figure 4.

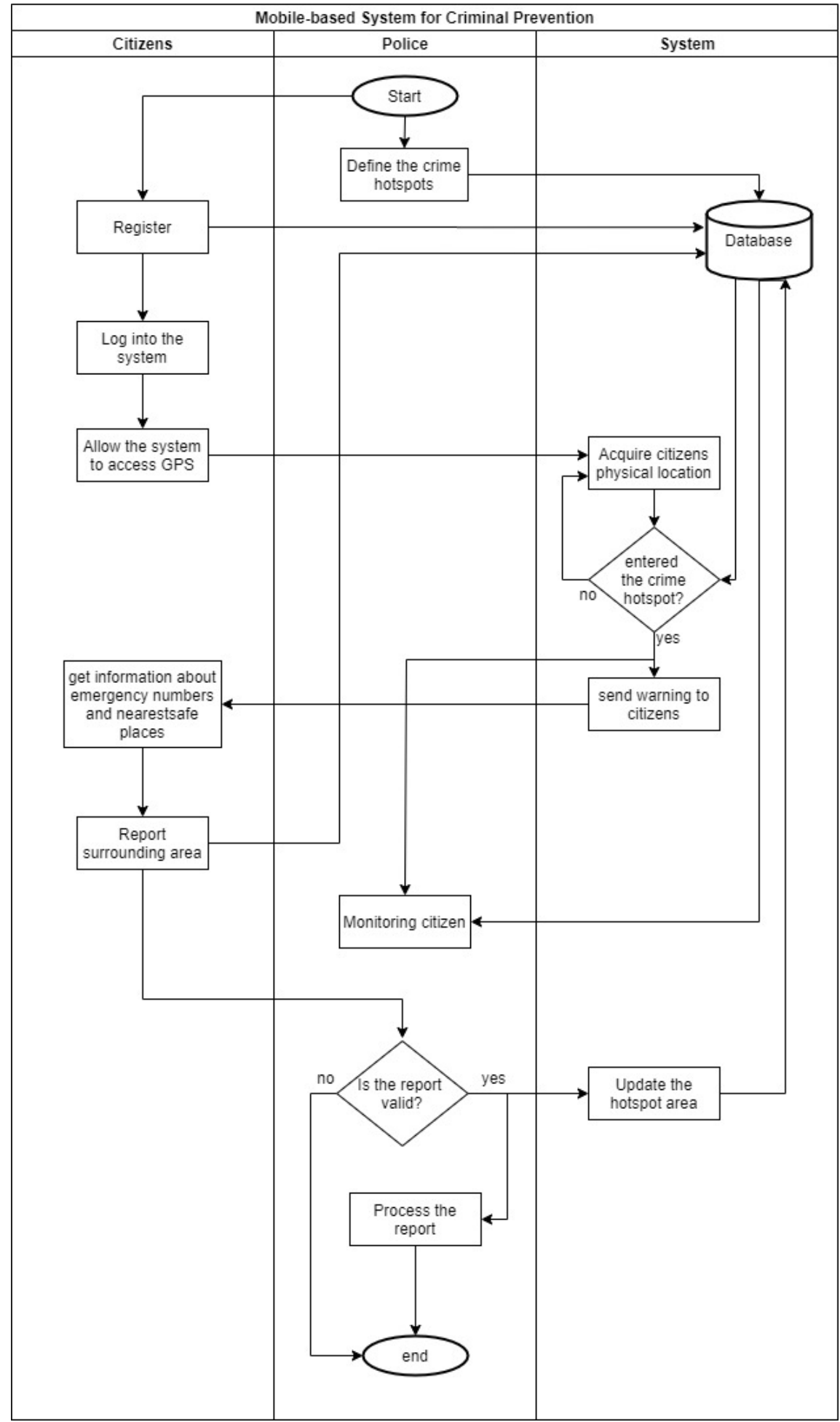

Figure 3. Process Flow of Criminal Prevention System 
In the system, the police define the crime hotspots in their territory and save the predefined locations to database as seen in figure 4 . The crime hotspots are not only determined by crime reports and history, but also by crowdsourcing data provided by citizen. The citizen can report the condition of their surroundings to the police. The system also enabled citizen to attach the evidence in the form of pictures, video, or voice recording. The picture, video, or voice recording must be capture directly using the application to ensure that the evidence represents the real situation to minimize the fake report.

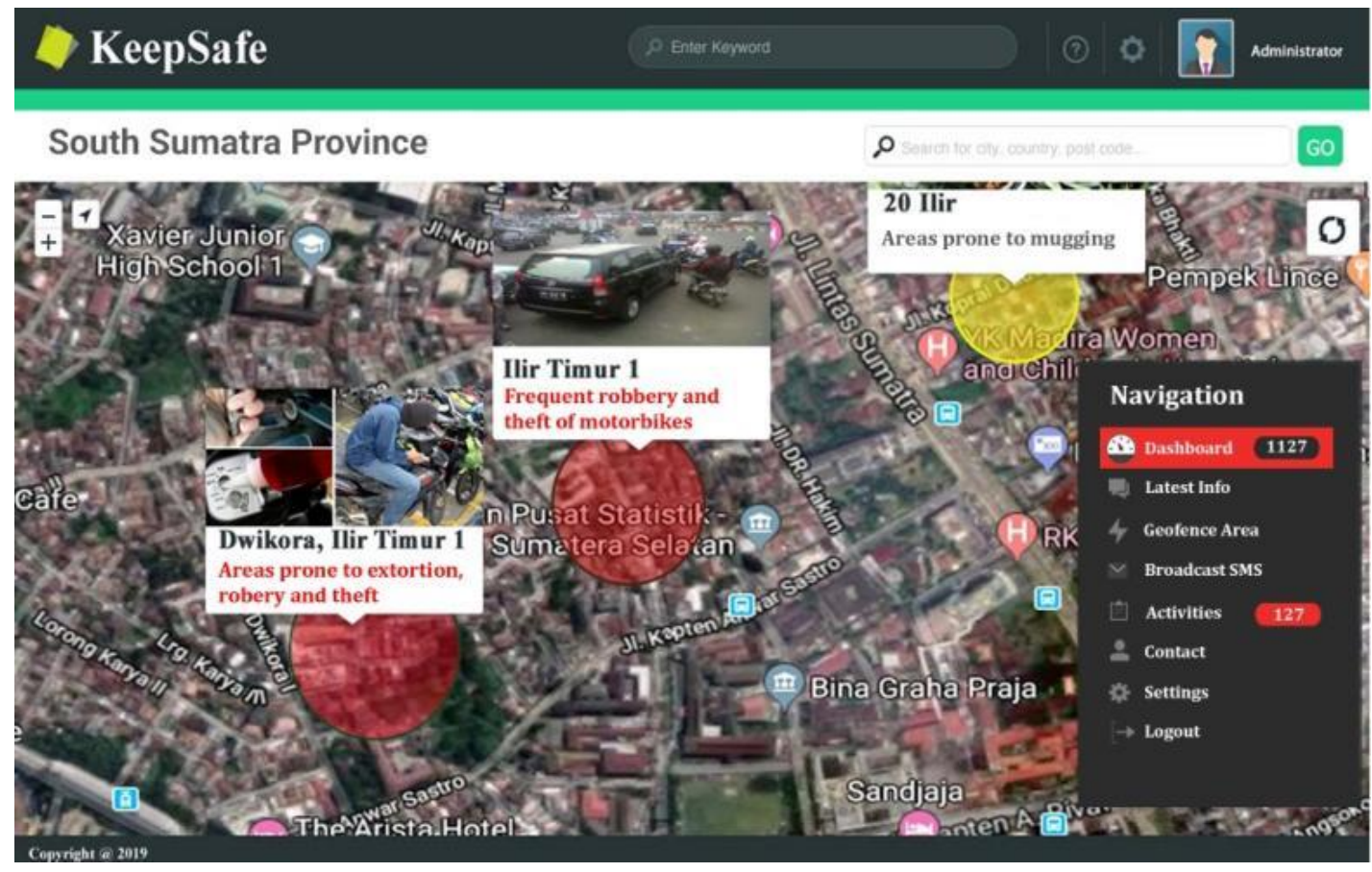

Figure 4. Crime Hotspot Monitoring Page

The system will notify the citizen and provide basic information about crime prevention when they enter the crime hotspot. Figure 4 shows the implementation of geo-fencing technique to generate warning when the citizen entered a crime hotspot area. Furthermore, the citizen can inquire more information about the emergency numbers (as seen in Figure 5) and the nearest safe places in an emergency condition. The system monitors the citizen who entered their territory, especially in the crime hotspots. When the citizen report their surrounding area to the system, the nearest police station will be notified. Furthermore, the police will process the report and determine the right action regarding the report.

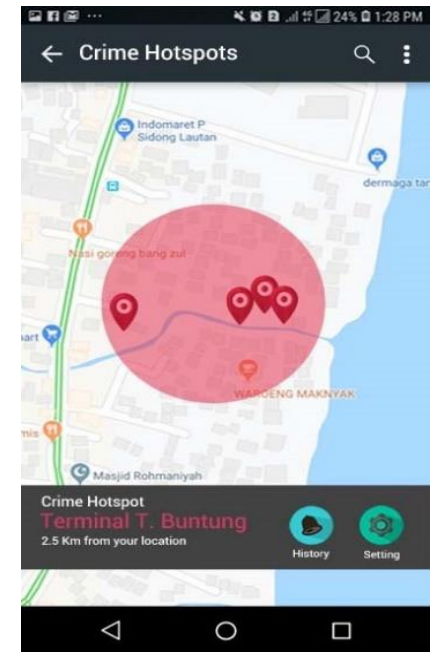

(a)

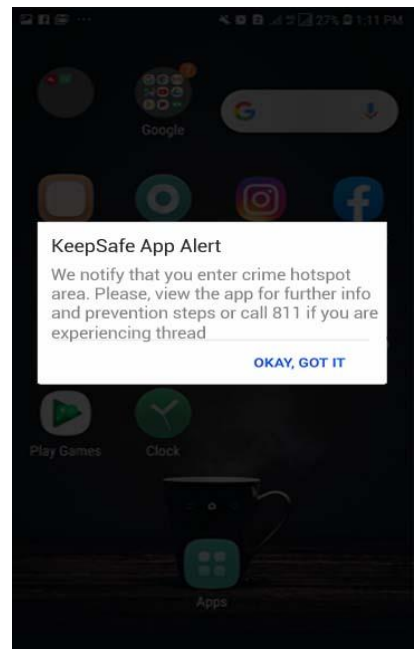

(b)

Figure 5. (a) Crime hotspot mapping and (b) notification alert 


\subsection{System Evaluation}

In this phase, we will evaluate the implementation of geo-fencing technique in application for crime prevention and user acceptance toward system adoption. The evaluation of geo-fencing implementation is conducted by created a virtual fence that represents a crime hotspot. A user, who represents the citizen, entered the predefined area to acquired information about the implementation of geo-fencing. In this experiment, testing is done using 15 devices where each device will enter the geofence area from 4 directions. Table 2 shows the result of the experiments to evaluate geo-fence implementation

Table 2. Experiment results

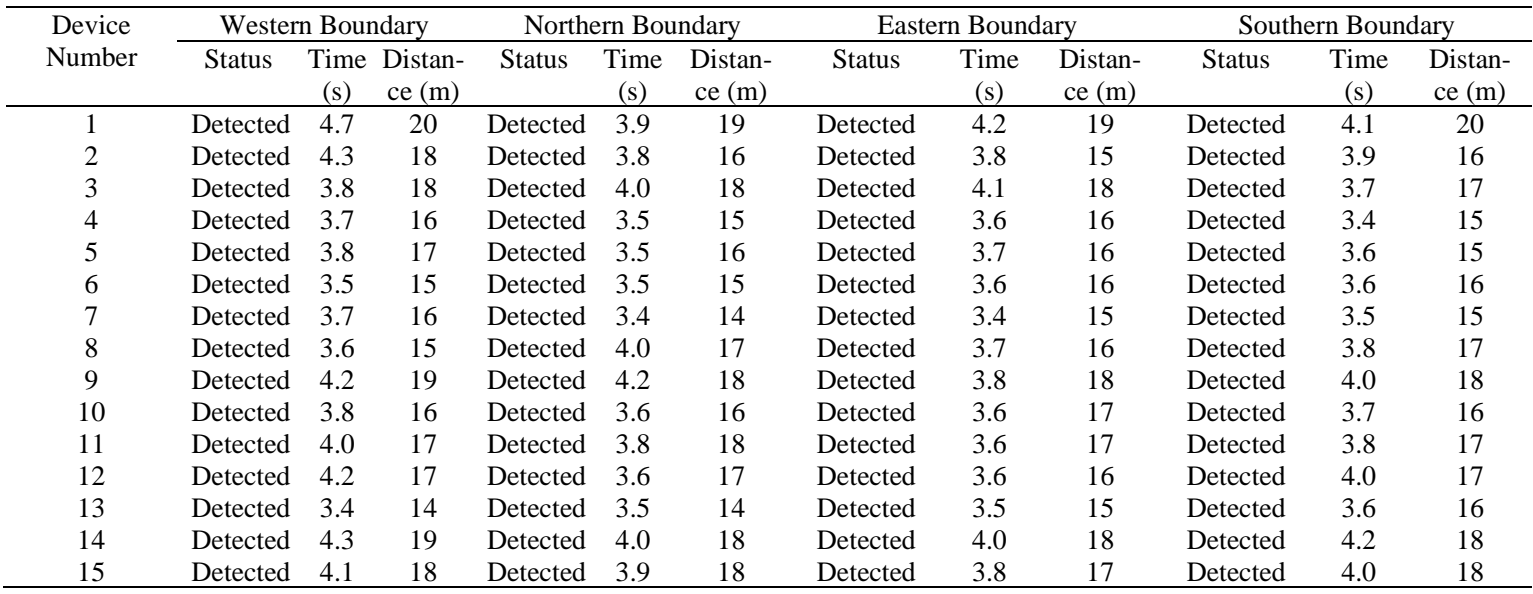

The result shows that system can detect devices when they entered a fenced area from different perimeters. User received the notification when they entered the crime hotspot area about 14 to 20 meters inside the fence with delay time around 3.4 to 4.7 seconds. The determining factors that affect the experiment results are GPS accuracy and internet connection. The GPS accuracy affects the system's ability to determine whether the citizen is in crime hotspot. Meanwhile, the internet connection will greatly affect the speed of data transmission performed by application. Based on the experiment result, the geofencing implementation was successful in monitoring users when they entering the crime hotspot area and providing information and warnings to prevent criminal acts against the user.

The user acceptance test adapted the user acceptance test (UAT) of Taherdoost[29]. The survey item can be seen in table 3 . The survey is filled with a likert scale from 1-5. 1 means very disagree; 2 means disagree; 3; neutral; 4 means agree; 5 means very agree. In this survey, 40 participants were engaged. Firstly, they use the system for three days. After that, the survey was conducted.

Table 3. UAT using Taherdoost's Questionaire

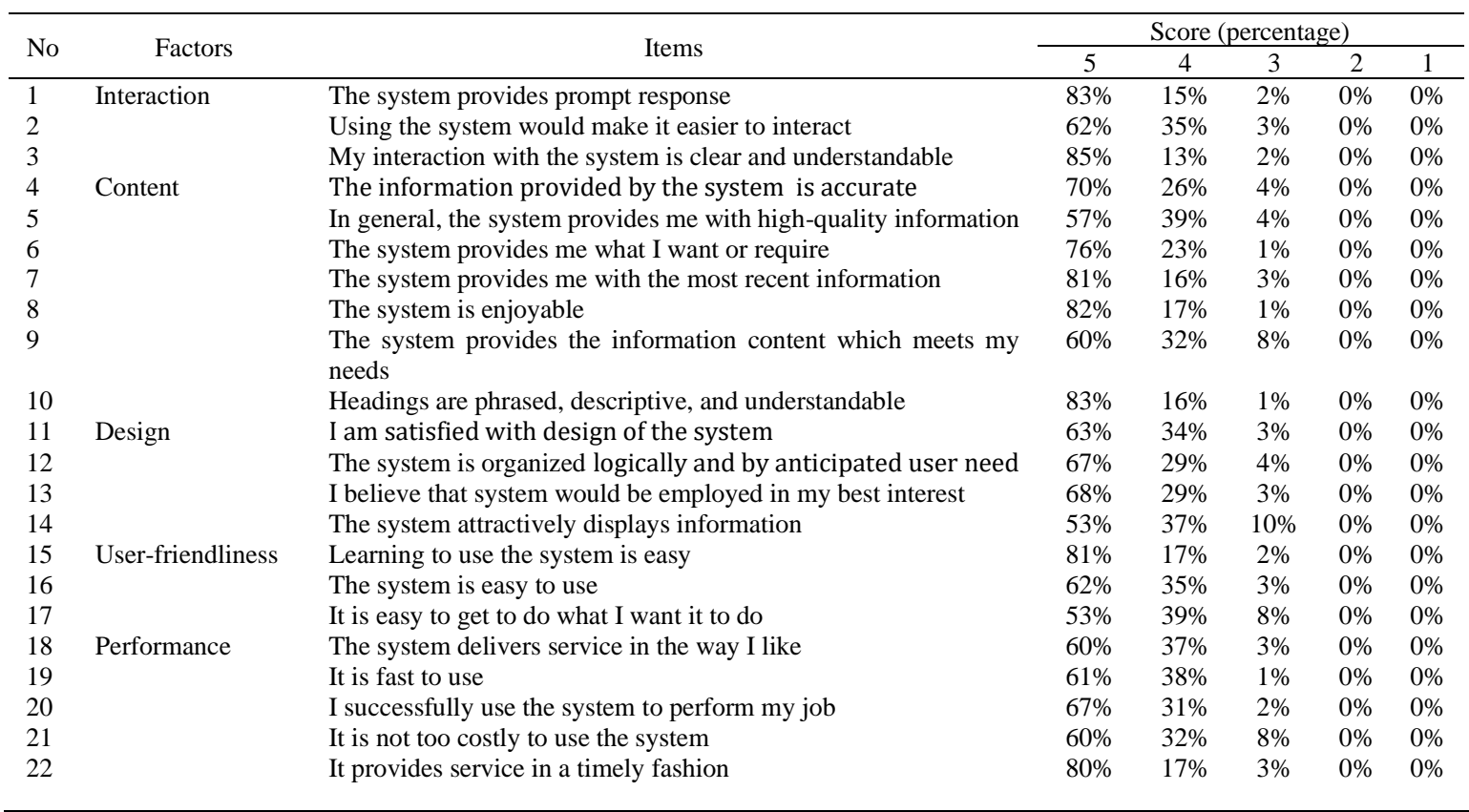




\begin{tabular}{|c|c|c|c|c|c|c|c|}
\hline 23 & & It makes information very accessible & $61 \%$ & $38 \%$ & $1 \%$ & $0 \%$ & $0 \%$ \\
\hline 25 & Usability & I accomplish the task easier and quicker with the system & $73 \%$ & $23 \%$ & $4 \%$ & $0 \%$ & $0 \%$ \\
\hline 27 & & Using the system is helpful and influential & $81 \%$ & $17 \%$ & $2 \%$ & $0 \%$ & $0 \%$ \\
\hline 28 & & The advantages of system are very important for me & $80 \%$ & $18 \%$ & $2 \%$ & $0 \%$ & $0 \%$ \\
\hline 29 & Expectation & The system will provide me flexibility to work & $70 \%$ & $21 \%$ & $9 \%$ & $0 \%$ & $0 \%$ \\
\hline 32 & Trust & $\begin{array}{l}\text { I feel assured that legal and technological structures adequately } \\
\text { protect me from problems on the system }\end{array}$ & $67 \%$ & $28 \%$ & $5 \%$ & $0 \%$ & $0 \%$ \\
\hline 33 & & $\begin{array}{l}\text { The system can perform the promised service dependably and } \\
\text { accurately }\end{array}$ & $65 \%$ & $28 \%$ & $7 \%$ & $0 \%$ & $0 \%$ \\
\hline 34 & & It is robust and safe & $76 \%$ & $20 \%$ & $4 \%$ & $0 \%$ & $0 \%$ \\
\hline 38 & & $\begin{array}{l}\text { In the system, if a certain transaction is performed, it never } \\
\text { could be denied by party }\end{array}$ & $68 \%$ & $30 \%$ & $2 \%$ & $0 \%$ & $0 \%$ \\
\hline 39 & Training & I have received the demo to use the system & $50 \%$ & $42 \%$ & $8 \%$ & $0 \%$ & $0 \%$ \\
\hline 40 & & I would use the system if I received training about how to use it & $55 \%$ & $38 \%$ & $7 \%$ & $0 \%$ & $0 \%$ \\
\hline 41 & Support & $\begin{array}{l}\text { A specific person (or group) is available for assistance with } \\
\text { system difficulties }\end{array}$ & $57 \%$ & $35 \%$ & $8 \%$ & $0 \%$ & $0 \%$ \\
\hline 42 & & $\begin{array}{l}\text { There is extensive support to help with problems related to } \\
\text { system }\end{array}$ & $60 \%$ & $34 \%$ & $6 \%$ & $0 \%$ & $0 \%$ \\
\hline 43 & Quality & Overall, the system works very well technically & $56 \%$ & $41 \%$ & $3 \%$ & $0 \%$ & $0 \%$ \\
\hline 44 & & The overall quality of system appears to me as being good & $63 \%$ & $35 \%$ & $2 \%$ & $0 \%$ & $0 \%$ \\
\hline 45 & & The quality of system is very good & $68 \%$ & $27 \%$ & $5 \%$ & $0 \%$ & $0 \%$ \\
\hline 52 & & $\begin{array}{l}\text { I intend to use the system rather than traditional service to do the } \\
\text { assignment }\end{array}$ & $86 \%$ & $12 \%$ & $2 \%$ & $0 \%$ & $0 \%$ \\
\hline 53 & Acceptance & I would feel comfortable using system & $80 \%$ & $16 \%$ & $4 \%$ & $0 \%$ & $0 \%$ \\
\hline 54 & & I have frequently used the system & $60 \%$ & $34 \%$ & $6 \%$ & $0 \%$ & $0 \%$ \\
\hline \multirow[t]{2}{*}{55} & & I would not hesitate to use system & $77 \%$ & $16 \%$ & $7 \%$ & $0 \%$ & $0 \%$ \\
\hline & & Overall Score & $69 \%$ & $27 \%$ & $4 \%$ & $0 \%$ & $0 \%$ \\
\hline
\end{tabular}

The UAT consists of 14 factors, which are interaction, content, design, user-friendliness, performance, usability, expectation, trust, security, training, support, quality, satisfaction, intention to use, acceptance. From the UAT, we can see that $69 \%$ of correspondences very agree that the system can be accepted and used. Meanwhile, 27\% agree that the system is appropriate to use while $4 \%$ are neutral.

\section{CONCLUSION}

In this paper, a mobile-based system for crime prevention is developed. The mobile-based system aims to increase citizen' knowledge and awareness of crime risk. The geo-fencing technique and crowdsourcing are implemented in the system. Geo-fencing technique is engaged in crime hotspots mapping and crime hotspots monitoring. Moreover, the crowdsourcing is employed to acquire potential crime hotspots information from citizen. The result shows that the system sent the notification when the citizen location was about 14 to 20 meters inside the fence. Using UAT, the system is well-accepted by users. Moreover, in the future, the system can engage more participants to use so that the new level of acceptance can be discovered.

\section{ACKNOWLEDGEMENT}

This work was supported by Universitas Sriwijaya and Database and Big Data Laboratory, Computer Science Faculty, Universitas Sriwijaya, Indonesia.

\section{REFERENCES}

[1] M. S. Hassan, M. S. Akbar, A. Wajid, N. Arshed, and others, "Poverty, urbanization and crime: Are they related in Pakistan," Int. J. Econ. Empir. Res., vol. 4, no. 9, pp. 483-492, 2016.

[2] P. E. Oguntunde and O. O. Ojo, "Analysis of selected crime data in Nigeria," Data Inbr., vol. 19, pp. 1242-1249, 2018. 
[3] A. Gouldson et al., "Exploring the economic case for climate action in cities," Glob. Environ. Chang., vol. 35, pp. 93-105, 2015.

[4] T. Lorenc et al., "Crime, fear of crime, environment, and mental health and wellbeing: mapping review of theories and causal pathways," Health Place, vol. 18, no. 4, pp. 757-765, 2012.

[5] T. Tajuddin, S. Supratman, D. Salman, and Y. Yusran, "Bridging social forestry and forest management units : Juxtaposing policy imaginaries with implementation practices in a case from Sulawesi," vol. 3, no. April, pp. 97113, 2019.

[6] GSMA, "Definitive data and analysis for the mobile industry," 2019.

[7] C. Oduor, F. Acosta, and E. Makhanu, "The adoption of mobile technology as a tool for situational crime prevention in Kenya," 2014 IST-Africa Conf. Exhib. IST-Africa 2014, pp. 1-7, 2014.

[8] T. Moses, A. La, and I. W. Andrew, "An Android Location-Based Crime Reporting System Using The Google MAP API."

[9] D. Singh, A. Das, A. Mishra, and B. K. Pattanayak, "Safety and Crime Assistance System for a Fast Track Response on Mobile Devices in Bhubaneswar," in Computational Intelligence in Data Mining, 2017, pp. 1-12.

[10] A. Muminov, D. Na, C. Lee, and H. S. Jeon, "Virtual fences for controlling livestock using satellite-tracking and warning signals," in 2016 International Conference on Information Science and Communications Technologies (ICISCT), 2016, pp. 1-7.

[11] G. Cardone, A. Cirri, A. Corradi, L. Foschini, R. Ianniello, and R. Montanari, "Crowdsensing in urban areas for city-scale mass gathering management: Geofencing and activity recognition,” IEEE Sens. J., vol. 14, no. 12, pp. 4185-4195, 2014.

[12] S. Shah, F. Bao, C. Lu, and I. Chen, "CROWDSAFE : Crowd Sourcing of Crime Incidents and Safe Routing on Mobile Devices ( Demo Paper )," in 19th ACM SIGSPATIAL International Conference on Advances in Geographic Information Systems, 2011, pp. 521-524.

[13] P. Sharkey, M. Besbris, and M. Friedson, "Poverty and Crime," in The Oxford Handbook of the Social Science of Poverty, no. June, 2018, pp. 1-17.

[14] S. MT, "Increasing Crimes vs . Population Density in Megacities," Soc. Criminol. Access, vol. 4, no. 1, pp. 1-2, 2016.

[15] J. Cheng, J. Liu, and J. Wang, "Domestic migration, home rentals , and crime rates in China," 2017.

[16] S. I. Chiodi, "Crime prevention through urban design and planning in the smart city era," J. Place Manag. Dev., 2016.

[17] Y. M. González, “'What citizen can see of the state': Police and the construction of democratic citizenhip in Latin America,” Theor. Criminol., 2017.

[18] S. Farrall, W. Jennings, E. Gray, and C. Hay, "Thatcherism, crime and the legacy of the social and economic 'storms' of the 1980s," Howard J. Crime Justice, 2017.

[19] S. P. Mohanty, U. Choppali, and E. Kougianos, "Everything you wanted to know about smart cities," IEEE Consum. Electron. Mag., 2016.

[20] Y. V Truntsevsky, I. I. Lukiny, A. V Sumachev, and A. V Kopytova, "A smart city is a safe city : the current status of street crime and its victim prevention using a digital application," vol. 01067, 2018.

[21] J. Byrne and G. Marx, "Technological Innovations in Crime Prevention and Policing . A Review of the Research on Implementation and Impact," no. 20, pp. 17-40, 2011.

[22] A. R. Gonzales, R. B. Schofield, and S. V Hart, "Mapping Crime : Understanding Hot Spots," 2005.

[23] S. Statler, "Geofencing : Everything You Need to Know," in Beacon Technologies, 2016, pp. 307-316.

[24] Y. Wang and M. A. Pérez-Quiñones, "Beyond 'geofencing': Specifying location in location-based reminder applications," in Conference on Human Factors in Computing Systems - Proceedings, 2015.

[25] A. Suyama and U. Inoue, "Using geofencing for a disaster information system," 2016 IEEE/ACIS 15th Int. Conf. Comput. Inf. Sci. ICIS 2016 - Proc., 2016.

[26] B. Nayak, P. S. Mugali, B. R. Rao, S. Sindhava, D. N. Disha, and K. S. Swarnalatha, "GeoFencing-Based Accident Avoidance Notification for Road Safety," in Emerging Research in Computing, Information, Communication and Applications, Springer, 2019, pp. 379-386.

[27] S. P. Raflesia, Firdaus, and D. Lestarini, "An Integrated Child Safety using Geo-fencing Information on Mobile Devices," in 2018 International Conference on Electrical Engineering and Computer Science (ICECOS), 2018, pp. 379-384.

[28] G. Miraglia and L. Hook, "Dynamic geo-fence assurance and recovery for nonholonomic autonomous aerial vehicles," in 2017 IEEE/AIAA 36th Digital Avionics Systems Conference (DASC), 2017, pp. 1-7.

[29] H. Taherdoost and H. Taherdoost, "Development of an adoption model to assess user acceptance of e-service technology: E-Service Technology Acceptance Model Development of an adoption model to assess user acceptance of e-service," Behav. Inf. Technol., vol. 0, no. 0, pp. 1-25, 2018. 


\section{BIOGRAPHIES OF AUTHORS}
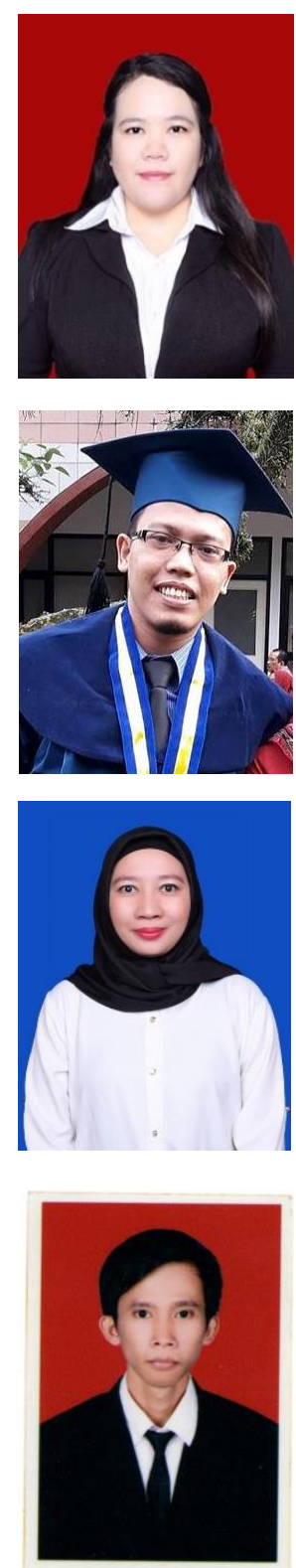

\section{Sarifah Putri Raflesia}

Sarifah is well-experienced in system development, business process re-engineering, and service excellence field. She graduated from School of Electrical and Informatics (STEI), Institut Teknologi Bandung (ITB), She actively joint research project in ITB in 2014-2016. She also worked as research and information system laboratory assistant in ITB. Now, she is an active researcher and lecturer in Department of Computer Science, Universitas Sriwijaya since 2016. Sarifah also has already published many research works in reputable journal and also international conferences. Now she has Scopus h-index $=4$, Google Scholar H-index $=5$, and WoS H-index $=$ 2.

\section{Taufiqurrahman}

Taufiqurrahman received his Master degree from School of Electrical and Informatics (STEI) Institut Teknologi Bandung, Indonesia. Currently, working as an Information Technology Engineer at Cyber Defence Center Ministry of Defence Republic of Indonesia and conducting research related to software development, cyber threat and malware analysis. His research interest include Cellular Automata, system development, data visualization, social media analytics, cyber threat intelligence and malware analysis.

\section{Dinda Lestarini}

Dinda Lestarini is an active lecturer in Computer Science Faculty, Universitas Sriwijaya. She received master degree in Informatics from School of Electrical and Informatics, Institut Teknologi Bandung (ITB). Her research interest including knowledge manangement, business process management, and information technology service management. She has already produced a number of research papers in reputable journal and conference. She has Scopus h-index of 3 and WoS h-index of 2. Currently, she serves as the head of database and big data laboratory in Computer Science Faculty, Universitas Sriwijaya.

\section{Ali Bardadi}

Ali Bardadi graduated from Universitas Diponegoro, Semarang. He started his research during his study about data mining and system development. He is now an active lecturer and researcher in Department of Computer Science, Universitas Sriwijaya. His research field involving data warehouse, business intelligent and information system. He also has extensive experience in system development. His Scopus $\mathrm{H}$-index=2; $\mathrm{WoS}=1$. 